\title{
Learning About Science in Preschool: Play-Based Activities to Support Children's Understanding of Chemistry Concepts
}

\author{
Karina Adbo ${ }^{1}$ (1) $\cdot$ Clara Vidal Carulla ${ }^{1}$ (])
}

Published online: 31 March 2020

(C) The Author(s) 2020

\begin{abstract}
The study explores children's emerging understanding of an important science concept in chemistry. Play-based learning activities were designed for children to experience and imagine the concept of 'small' as used in chemistry, moving from the visually experienced level of 'small' towards more imaginative understandings. Data were collected through visual ethnography. Analyses of six vignettes of conversations between children and the teacher illustrate development of children's understanding of the focus concept. Deconstruction of everyday items familiar to the children and visual computer animations provided experiences that enabled children to transition from a macro-level of understanding to visualise the molecular/ atomic level to differentiate between macro- and micro-understandings of 'small'. A process of 'sustained shared thinking' could describe the teaching/learning processes evident in the children's and teacher's conversations. The analyses suggest that sustained and shared conversations between children and teachers should stem from children's everyday experiences.
\end{abstract}

Keywords Emergent science · Preschool · Theoretical chemistry · Visual ethnography, sustained shared thinking $\cdot$ Play-based activities

\section{Résumé}

L'étude explore chez les enfants la compréhension émergente d'un concept scientifique important en chimie. Des activités d'apprentissage basées sur le jeu ont été conçues pour que les enfants expérimentent et imaginent le concept du 'petit' tel qu'il est utilisé en chimie, en passant de la découverte visuelle au niveau du 'petit' vers des compréhensions plus imaginatives. Des données ont été recueillies par le biais de

Karina Adbo

karina.adbo@1nu.se

Clara Vidal Carulla

clara.vidalcarulla@lnu.se

1 Department of Biology and Environmental Sciences, Linnaeus University, SE-391 82 Kalmar, Sweden 
l'ethnographie visuelle. L'analyse de six vignettes de conversations entre les enfants et l'enseignant illustre le développement chez les enfants de la compréhension du concept examiné. La déconstruction d'objets quotidiens familiers pour les enfants et d'animations visuelles sur ordinateur ont fourni des expériences qui ont permis aux enfants de passer d'un niveau de compréhension macro à une visualisation du niveau moléculaire /atomique, et de faire la différence entre les compréhensions macro et micro du 'petit'. Un processus de 'pensée partagée soutenue' pourrait décrire les processus d'enseignement /apprentissage évidents dans les conversations entre enfants et enseignants. Les analyses suggèrent que les conversations soutenues et partagées entre les enfants et les enseignants devraient découler des expériences quotidiennes des enfants.

\section{Resumen}

El presente estudio explora la comprensión reciente de los niños de un importante concepto de ciencia en el campo de la química. Se diseñaron actividades lúdicas de aprendizaje para que los niños experimentaran e imaginaran el concepto de tamaño "pequeño" según se utiliza en el campo de la química, alternando entre el nivel de experiencia visual del concepto "pequeño" hasta una comprensión más imaginativa. Se recolectó información por medio de etnografía visual. Análisis de seis fragmentos de conversaciones entre los niños y el educador ilustraron el desarrollo de la comprensión de los niños del concepto principal. La deconstrucción de elementos cotidianos comunes para los niños y las animaciones visuales computarizadas brindaron experiencias que les permitieron a los niños navegar desde un nivel macro de comprensión a visualizar el nivel molecular/atómico, así como diferenciar entre la comprensión macro y micro del concepto "pequeño". Los procesos de enseñanza/aprendizaje que se evidencian en las conversaciones entre niños y educadores se pueden describir mediante un proceso de "constante pensamiento común". Los análisis sugieren que conversaciones constantes y compartidas entre niños y educadores deben emanar de las experiencias cotidianas de los infantes.

\section{Introduction}

During recent decades, numerous educational reforms have aimed to promote the scientific literacy of young children (Siry et al. 2012). The present study was conducted in Sweden where the preschool guidelines and curricula have become more subject specific, over time, in their focus on natural science content. This formulation has occurred in the preschool guidelines, since 1998. In the 2018 revision of the guidelines, this focus is indicated as: '... The preschool should strive to ensure that each child develops his/her understanding of science and relationships in nature, as well as knowledge of plants, animals and simple chemical processes and physical phenomena.' (National Agency for Education 2018, p. 10). This study explores how preschool programs can convey understanding scientific understanding about chemistry to preschool-aged children. 
Research efforts aimed to support science-specific understanding by young children have been evident in fields of biology and physics (Russo 2008; Allen 2015; Fragkiadaki and Ravanis 2015; Sackes 2015), and there has been less focus on chemistry. Meaningful understanding by young children about the concepts of chemistry is dependent on how well teachers can develop appropriate activities and understand how children interpret these experiences (Adbo and Vidal Carulla 2019). This research describes such a process to support emergent understanding about chemistry through an educational experiment (Hedegaard 2008). Activities are designed and evaluated through an iterative process to support learning about science.

Chemists adopt a particular perspective about the surrounding world. They see it as made up of particles of different sizes that are in continuous motion taking part in processes of assembly and disassembly. There are difficulties in imagining this sub-microscopic (non-visual) level of the world. This challenge has been described for decades (Novick and Nussbaum 1978). However, despite numerous educational studies at various levels of education, the difficulty in imagining this sub-microscopic level remains a critical issue for education. This research provides a demonstration about how children's imagination can be used to provide them with new insights about theoretical ideas in chemistry and how they might be introduced, not just for preschool, but also in other levels of education.

\section{Emergent Science Education and Play-Based Learning}

Emergent science is a terminology first used by Siraj-Blatchford (2001) to describe a science perspective for early years education. This perspective considers that science activities are socially situated, driven by exploration of scientific phenomena and positive engagement. Important in this perspective is that children's emerging knowledge is a continuous and ongoing process (Larsson 2013), in which children's expressed interests in science are the focus. When the term 'children's emergent science' or 'emergent chemistry' is used within this text, it refers to children's expressions of interest and understanding of science content.

Ideas presented in this research are informed by cultural-historical theory (Hedegaard and Fleer 2013) and play-based learning approaches (Fleer 2015). This includes theoretical assumptions about children's learning, the role of the teacher, and ideas about natural science. Play-based learning takes account of the design of activities and the teaching and learning processes in preschool settings. Within early childhood education, play is seen as 'the leading line of development in the preschool years' that supports both emotional and intellectual developments (Vygotsky 2016, p. 6).

An important aspect of learning in play-based settings is imagination. This is defined by Hedegaard (2016) as the interaction between a school's practices and the children's motive orientation. Imagination provides the means for children to separate emotions from events and activities. This is an essential part of learning and is the source of creativity that helps humans to imagine what they cannot see, conceptualise what they hear from others, and think about what they have not yet experienced' (Fleer 2015, p. 39). From this view of children's development, the fact 
of creating an imaginary situation can be regarded as a path to developing abstract thought (Vygotsky 2016, p. 20). The transfer of experience from others is an important part of providing children with new experiences but also raises questions about if and how design of activities can help children extend their thinking beyond direct sensory experiences.

Within play-based learning, the teacher is a participant in the play and is a mediator of knowledge by respectfully partaking in the play and supporting children by finding common ground and creating shared meaning (Siraj-Blatchford 2009). This process of 'sustained shared thinking' describes the actual teaching/learning process within an educational environment and suggests that the topic of conversation between a child and the teacher originates from the child's everyday experiences. These ideas and experiences can be shared among all participants including the teacher.

The teacher can include science words and concepts into interactions with children, and moments of sustained shared thinking can be created. This dynamic change can refer to conceptual play (Fleer 2011). All types of learning, including science learning, are here seen in a dialectical manner, because interactions between the child/teacher and the concept/context affect the child's learning, as the child also affects the interaction (Fleer 2011).

\section{Science Content for Preschool}

Learning activities within preschool can be designed to take a holistic approach. Science skills, practical science methods, and science concepts may all be considered in the content of activities. Some examples of science skills, as derived from Johnston (2014), are observing (using all senses); classifying (finding similarities and differences); and predicting ('What might happen if ...?'). In chemistry, science methods include tasks performed in most kitchens, such as filtering, grinding, and mixing.

Natural science encompasses numerous scientific words and concepts that may be all connected in specific ways. A word can be seen as a label with limited content, such as the name of an object (Eshach 2006). If the word is derived from the child's everyday experiences in the world, it is defined as an everyday word. If the word is related to science and has been intentionally introduced by the teacher, it can be considered a science word.

Concept formation, as described by Vygotsky (1987), encompasses two levels: everyday and scientific. At the everyday level, concepts are learned as a result of interacting directly with the world. This is about development of intuitive understandings about how to do things. These everyday concepts lay the foundation for learning scientific (or academic or school) concepts. For the child in a learning situation, everyday and scientific concepts are interrelated in such a manner that enrichment in one will affect the other and vice versa. Thus, new ways of relating to the scientific world are provided. Careful planning by the teacher is required, especially with respect to science content. This process is referred to as the 'double move' in teaching (Hedegaard and Chaiklin 2005, p. 70). 


\section{The Current Study}

This research explores emergent understanding of preschool-aged children about the scientific concept of 'small', as used in theoretical chemistry. This concept is introduced in play-based learning activities within a preschool in Sweden. The research aim is to provide activities that support children to gain greater understanding of this scientific concept, including moving from a visually experienced level of what small means towards a more imaginative understanding of its meaning. Through a playbased approach, children can learn to imagine a world beyond their direct sensory experience to gain some understanding of the sub-microscopic molecular/atomic level of 'small'.

The research objectives are

- What features characterise children's emergent scientific understanding of the concept of 'small'?

- How can early childhood teachers design activities to support and provide experiences that enhance children's emergent understandings of concepts in chemistry?

\section{Method}

\section{Research Context}

A preschool located in a small town in south-eastern Sweden volunteered to participate in the study. The town is rural with little industry, and the municipality has a population of 70,000 people. The two major employers in the town are the county hospital and the university. The group in focus in this research are four children (two boys and two girls), aged between three and five years, at the time of the data collection. The children were from families with two caregivers, and the children were native Swedish speakers. School in Sweden is not compulsory until Grade 1 (7 years of age), although $85 \%$ of all children in Sweden who are aged 1-4 years of age attend preschool (Sveriges Kommuner och Landsting 2017).

\section{Ethics}

This research project was approved by the National Ethical Board (Linköping Dnr/451-31). Informed consent for the study was obtained from all parties involved, including the preschool principal, teachers, parents, and children. All data collection and information storage complied with the General Data Protection Regulation (GDPR; EU Regulation 2016). Only children whose parents consented to their participation in the study were included in the data collection. In order to ensure consent (to the best of our abilities) on a daily basis from the 
participating children, regular staff were present during the activities to make sure that the children were comfortable while participating. Consent included publishing rights. Aliases have been used to protect the participants' identities.

\section{Research Design}

Data presented in these analyses were drawn from a longitudinal study that explored children's emerging understandings of science. This study took place across a period of 2 years. At the beginning of the study, the participating children were aged 3 years, and the study was completed by the time the children reached the age of 5 years.

This part of the project focuses on the scientific concept of small. At the beginning of the project, the smallest things these children could imagine were 'baby geese' and 'insect babies'. It was difficult for the children to imagine things smaller than what they could see with their direct senses. At this time, the children were aged between 3 and 4 years of age.

In order to provide children with a breadth of experiences of the concept of small, two stages for the activities were designed. Stage 1 focused on the deconstruction of everyday objects (i.e. broken down into smaller pieces by the children, by using either their hands or a mortar). Examples of the objects deconstructed included a leaf, salt, a sugar cube, and a bath bomb. The children looked at the 'smaller' pieces with the help of magnifying glasses and portable microscopes (magnifying 100x).

The deconstruction activities were designed specifically to provide experiences of taking things apart to explore if the process of taking things apart and observing the smaller and smaller pieces would enable the children to begin to imagine the non-visual level of the items at hand. Based on the children's experience in the activities in Stage 1, a second set of activities was then designed (Stage 2). This second set of activities included video animations. The duration for all activities ranged from 15 to $30 \mathrm{~min}$, and the activities took place twice a week.

\section{Visual Ethnography}

Visual ethnography was the method chosen for data collection as it includes 'active collaboration with the research participants in the process by which knowledge is produced' (Pink 2014, p. 117). Action cameras were strategically placed around the preschool room to ensure recordings from all possible angles. Within this method, the researcher is included in participatory observation (i.e. leading the video-recorded activities). This method provides the means to include 'views, perspectives, beliefs and values' (Siraj-Blatchford 2010, p. 271) of all involved in the context that is being studied. The comprehensiveness nature of the audio-visual recordings helped to overcome the partial view of the participant-observer on any single event. 


\section{Data Analysis}

Within these analyses, the development of the concept of 'small' was the unit of analysis. Analysis of the difference between a concept and a word was done in the following manner: a word was seen as a repetition of a spoken word or a word used without further explanation or body language. A concept was seen as including further content or being related to everyday items with similar function or resemblance. In order to describe children's emerging understanding of the concept of small, data were analysed longitudinally.

The use of signs and symbols is a key aspect in cultural-historical theory (Veresov 2010). Indeed, 'human action is built through simultaneous deployment of a range of quite different kinds of semiotic resources' (Goodwin 2000, p. 1489). For this reason, conversation analysis was chosen as the method used for analysing the discourse in the play-based activities. This method includes a range of important considerations, such as the sequence of the events or interventions during the conversation (Heritage 1984) and the affective stance, including intonation, gesture and/or body language (Goodwin et al. 2012), together with all the aspects of multimodality, such as lexicon, prosody, and use of artefacts (Mondada 2018). The transcription conventions used in this paper are outlined in 'Appendix'.

\section{Results}

Data derived from the two different stages in the design of activities are presented sequentially to illustrate the iterative process in design of the activities. The data presented are drawn from a selection of critical episodes (Siraj-Blatchford 2010) and are presented as six vignettes that illustrate significant child and teacher interactions. The focus of the vignettes is identified in Table 1. The first set of activities (deconstructions) were analysed, and this analysis then provided the backdrop for the development of a subsequent set of activities (video animations).

Table 1 A summary of all the vignettes included in the results presentation

\begin{tabular}{lll}
\hline & Vignette & Stage \\
\hline Activity 1 & The microscope and the leaf & Deconstruction \\
Activity 2 & The mortar and salt & Video animation \\
Activity 3 & The leaf video animation & \\
Activity 4 & Revisit of the leaf video animation & \\
Activity 5 & The water video animation and molecular set & \\
Activity 6 & Revisit of the butterfly and the leaf video animations & \\
\hline
\end{tabular}




\section{Stage 1-Deconstruction Activities}

Two activities are described in this section, and the selected vignettes illustrate the interactions between the teacher and the children involved in the deconstruction of a leaf (Activity 1) and salt crystals and sugar cubes (Activity 2).

In Activity 1, three children (Peter, John, and Sofie) participate. The portable microscopes used in this activity had 100 times magnification. The children looked at a leaf using microscopes.

\section{Vignette 1: The Microscope and the Leaf [15th October 2018]}

1. John A telescope.

2. TEACHER Right, telescopes are for looking at stars in the sky, but this is a microscope.

3. TEACHER Let's look at the leaves, what can we see?

4. John I don't know how to draw a leaf.

5. John Now we can look at these and see what they look like.

6. John *pointing at his leaf*

7. TEACHER Do you remember that you need to close one eye?

8. John *covers his left eye and looks through with his right eye*

9. John I can't see anything.

10. TEACHER Do you see something yellow? That is the leaf.

11. John I see some spots, like a cheetah.

12. TEACHER Nice.

13. TEACHER Can you see anything, Sofie?

14. Sofie No, I see nothing.

15. John I think it is too black.

16. TEACHER Maybe it is too dark, you are right, it can be like that.

17. Sofie It is too dark.

18. John It is as black as Batman.

19. TEACHER It is not easy seeing things through a microscope.

20. Sofie You can do like this.

21. Sofie *pretends to hold a microscope and look at the leaf* 
From this initial activity about deconstruction, the children connect what they see in the microscope with their everyday experiences. Spots on the leaf became spots 'like on a cheetah' (Line 11), and the black part of the leaf was compared to Batman, 'black as Batman' (Line 18). Their descriptions were presented as a matter of fact without any hesitations. Here the understanding of how to use the microscope was initially made by John, who made the connection to an everyday experience of a telescope (Line 1). The use of the microscope was supported by the teacher who triggered a memory of a previous experience (Line 7). This exploration of magnification was initiated by the children, playing with the level of magnification through changing the distance between the magnification glass and the leaves. In this vignette, it is not clear if the children perceived the visual spots as small.

In Activity 2, the children (John, Peter, Sofie, and Maria) were asked to look at salt crystals and sugar cubes, which were later ground into smaller pieces using a mortar. All four children were present during this activity. The following discussion took place.

Vignette 2: The Mortar and Salt [18th October 2018]

1. John I can see it is getting bigger.

2. Peter I got the smallest.

3. Sofie I got the biggest.

4. Peter I got the smallest.

5. Peter * grumpy face*

6. Maria I got a middle-sized one.

7. Sofie I see it.

8. TEACHER What do you see?

9. Sofie I see a lot of small ice blocks.

10. John I see a lot of cute things made of salt and powder.

11. TEACHER Aha...

12. Sofie There is a lot of snow in it!

13. Maria $*$ *moving magnifying glass away from the crushed sugar cube*

14. Maria It gets bigger.

15. Sofie Look, it looks like rocks.

16. Maria I am going to draw this.

17. TEACHER Exactly.

18. Sofie I am going to draw small crumbs from the sugar cube, like this.

19. Sofie *looking through the magnifying glass*

20. Sofie Look, they get bigger and bigger. 
In this activity, the children again to a large extent used their everyday words and experiences to describe what they saw. The ground sugar was described as ice blocks' (Line 9) and 'snow' (Line 12). But other types of descriptions also began to emerge, descriptions that were of a more general and unspecified type, such as 'cute things' (Line 10). The word, 'small', was used in connection with 'small crumbs' (Line 18) and powder (Line 10); small was indeed seen as small parts of something instead of being seen as a smaller version of a whole item or animal (such as baby geese). The children showed an understanding of the magnifying process, exploring how things get bigger when the magnifying glass was moved further away from the sugar (Lines 115 and 20).

\section{Stage 2: Video Animation Activities}

Results from the deconstruction activities showed that although there were traces of generalisations in the children's descriptions, the children did not naturally use their imagination in this context to extend their experiences to a non-visual level. As a result of these findings, another four activities were specifically designed in order to explore the result of providing visual experience of the non-visual level of chemistry. The four activities consisted of looking at video animations, for example, that zoomed in on trees from a distance, to a leaf on the tree, and then specifically to the molecular/atomic level of the leaf. The video animations show zooming in with magnification on: a leaf, a butterfly, and water.

In Activity 3, two computer animations of a leaf and a butterfly were used in an attempt to provide new visual experiences of the concept of small. For example, the video animations showed trees and then slowly zoomed in closer onto a leaf to the stomata (i.e. plants 'breathe' too-tiny openings in leaves that open and close to allow intake of carbon dioxide and release of oxygen) and further down to the atomic/molecular level. The second computer-animated video slowly zoomed into a butterfly in a similar manner until reaching the atomic/molecular level. The following discussion took place while the children were looking at the molecular level of the leaf.

\section{Vignette 3: The Leaf Video Animation [25th October 2018]}

$\begin{array}{ll}\text { 1. John } & \text { A hole. } \\ \text { 2. Maria } & \text { A lot of meatballs. } \\ \text { 3. John } & \text { And peas. } \\ \text { 4. Maria } & \text { Meatballs. } \\ \text { 5. Sofie } & \text { I think they are trees. } \\ \text { 6. Sofie } & \text { What is this? } \\ \text { 7. Maria } & \text { They are peas. } \\ \text { 8. John } & \text { I knew that. } \\ \text { 9.John } & \text { But it is almost like water. } \\ \text { 10. Sofie } & \text { Spider web. }\end{array}$


11. Maria I want to look at the peas.

12. John There are flat things.

13. Maria They are peas that need to be pumped up with pea flour.

The video animations provided the children with experiences at a different visual level that helped them to appreciate that even butterflies and leaves have different kinds of elements within them. The descriptions used to explain what they saw were meatballs (Line 2), peas (Line 3) and trees (Line 5) at the stomata level, and water (Line 9) and a spider web (Line 10) when referring to the molecular level, which showed transparent atoms and molecules. The only suggestion that what they saw was indeed very small was presented by Maria, who suggested that the flat structures in the leaves were peas that just need to be filled with (smaller things such as) pea flour (Line 13). Pea flour was thus far the smallest thing described. The animation also provided three-dimensional structures to the children's descriptions, as there were not only meatball-like structures (Lines 2 and 4), but also flat structures (Line 12) that were assumed to become rounder if pumped up with pea flour (Line 13).

The vignette in Activity 4 took place after the Christmas break in the school year and began as a recollection of the video animations by replaying them.

\section{Vignette 4: Revisit of the Leaf Video Animation [8th January 2019]}

1. John I remember those... those... almost like meatballs.

2. TEACHER Good memory.

3. Sofie In autumn, all the leaves fall down.

4. Sofie *swings her hands to the ground like a leaf*

5. TEACHER Exactly, that is why we find so many on the ground.

6. John And they have a long cone on them, so they can ... hold to the tree.

7. John *joins his finger to his other hand illustrating how the leaf hangs on the tree*

8. Sofie The leaf.

9. TEACHER We are getting closer to the leaf ... and what is this?

10. John An ant.

11. Sofie There are more ants.

12. Peter Now we are going in.

13. Sofie I thought they were maggots.

14. John Here is the hole.

15. Sofie Here are the meatballs!

16. John They are NOT meatballs, they just LOOK LIKE meatballs.

17. Sofie This looks like a tree! And now we are going in there.

18. Sofie And this looks like a racetrack. What is this? 
19. John This looks like rocks.

20. TEACHER This is what we are going to be working with today.

21. TEACHER These small balls are called atoms.

22. Peter Atoms?

23. TEACHER Yes.

When the video began, John immediately remembered the meatballs (atoms) (Line 1), showing that the experience had been meaningful for him as there had been 3 weeks' pause in activities over the Christmas period. The teacher reinforced John's comment by commenting that he had a good memory. It was possible that it was this reinforcement that caused Sophie to identify the meatballs in the next video animation. This identification, in turn, caused John to specify what he meant by his initial statement regarding the meatballs, that they were in fact not meatballs (Line 1); they just looked like meatballs (Line 16). The descriptions had been exchanged for a realisation that things may not actually be what they looked like (Lines 16-19). At this point in time, the teacher helped the children to label the description of what the things that looked like meatballs were, by introducing the word 'atom' (Line 21).

In Activity 5, there were only two children present. The focus of this session was to explore video animations further. Initially in this activity, a video amination of zooming in on a drop of water was shown to the children and, after the video, water molecules were built using a molecular set. Then, a video animation of water changing from solid to liquid and gaseous form was also shown to the children. The following discussion took place during this activity.

\section{Vignette 5: Water Video Animation and Molecular Set [19 March 2019]}

1. TEACHER With one red atom and two white atoms, we are going to build a molecule.

2. Maria It looks like Mickey Mouse.

3. TEACHER Right, the head with two ears, but this represents a water molecule, look.

4. TEACHER What is this? (showing water drop video animation)

5. Maria A water drop.

6. TEACHER Exactly, and we get closer, what do we find inside?

7. Maria Molecules.

8. John Molecules.

9. TEACHER What did we have here? (showing ice-water-gas transition animation)

10. John Boiled water.

11. Maria Water and ice.

12. TEACHER Right. 
13. TEACHER What came out of the water when it was boiling?

14. John These.

15. John *pointing at the water molecules*

16. John Like in the shower, the tap, in the swimming pool ...

17. Maria And there are water molecules.

18. TEACHER Yes, everywhere.

20. John In all the water.

The shape of the water molecule could easily be connected to everyday experience in the form of Mickey Mouse (Line 2), and when the video zoomed in towards the molecular level, the children easily recognised the shape of the molecules they had built using the molecular set (Lines 7 and 8). While watching the video about the water molecules changing states, which had the accompanying sounds of cracking ice, a running stream of water and water boiling, the children could easily identify and name each state (Lines 10 and 11). The summarising of what had been done so far and what was remembered from other activities concerning water provided means for connecting the new experience of water molecules to different contexts in which the children can find water, like a shower, a tap, or a swimming pool (Line 17). As the children had begun to connect molecules to water (Lines 14, 15, and 18), the previous video animations were yet again revisited, in order to see if the water molecule experience would contribute to their descriptions of the molecular level of the leaf and the butterfly.

For Activity 6, only John and Maria participated. They were shown again the video animations which they had seen in the previous sessions.

\section{Vignette 6: Revisit of Butterfly and Leaf Video Animations [20 March 2019]}

1. TEACHER What do we have here?

2. John I see a butterfly.

3. Maria We go inside the butterfly.

4. John We see a tiny, tiny hole.

5. Maria We get closer to the wing.

6. John This is the wing.

7. TEACHER Exactly.

8. TEACHER And what do you think these tiny balls are? (pointing at atoms in a molecule)

9. John RIGHT. Those we find in water.

10. John *stands up and looks perplexed*

11. TEACHER Precisely, those things we talked about yesterday, atoms. 

12. Maria Atoms, yes.
13. TEACHER Looking into the butterfly's wing, we have found atoms.
14. Maria
Atoms, atoms.

15. TEACHER What do you see here? (pointing at atoms in a molecule)

16. Maria Peas.

17. John This kind of peas or meatballs.

18. Maria Meatballs and peas in the inside.

19. Maria But this is inside a leaf.

20. TEACHER Right.

21. John THESE ARE ATOMS.

21. TEACHER Exactly.

22. John They are in the water, in the butterfly and in the leaf.

23. TEACHER If we looked at our skin with the best microscope in the world, we could also see atoms. They are everywhere.

24. John

*nods with his head*

After being shown the video with the zooming in on a butterfly's wing, John came to the realisation that the tiny balls were also in the water drop (Line 9). Maria confirmed the word (Line 12) and repeated it (Line 14). Once they had watched the leaf video again, Maria still suggested that what she saw were peas (Line 16), whereas John made the remark that they just look like that (Line 17). When Maria points out that the meatballs and peas are within the leaf (Lines 18-19), John again states that they are atoms (Line 21). This activity provided John with the means to connect experiences from different activities and reach the conclusion that atoms exist in everything, not only in the water and leaves (Lines 22 and 24). Maria still did not verbalise her opinion, possibly due to the fact that John was very excited and loud (Lines 9, 10 and 21).

\section{Reflections on Children's Learning}

The emergence of understanding of the scientific concept of 'small' by the children included a shift to more abstract thinking. Initially, the children's descriptions of what they saw were presented in the form of self-assured statements drawing on their everyday experiences. These descriptions were then slowly transformed into recognition that things may not be exactly what they seem, a realisation that is important in abstract thinking.

The deconstruction activities supported the emergent understanding of the concept of small as it evolved to include different features of items and not just smaller versions of the item at hand. Descriptions included references to 'tiny crumbs' and the content of 'peas', here referred to as 'pea flour'. But the actual act of breaking things down to smaller and smaller pieces and looking at the pieces at different levels of magnification did not provide support enough for the children to take a step further and begin to imagine at a non-visual level. It was not until a 
computer-generated visual experience of a non-visual level was introduced using video animations of the transition between the two levels that the children began to realise that there are different kinds of smaller things within everyday items such a leaf and a butterfly ('We go inside the butterfly'), leading to awareness of a non-visual level in which atoms and molecules exist. Using the video animations to zoom in gave the children opportunities to see the actual transition and provided means for generalising their observations across different animations. An emergence of the concept of magnification using the magnifying glass supported by repetitive use of a series of activities also changed children's thinking. Initially, the children focused on the magnifying effect and did not acknowledge that the items they looked at were in fact small but appeared bigger in the magnifying glass. After repetition of activities, the children changed their focus and realised that the item just appeared to be big and that it was, in fact, 'small'. This development of understanding required support from the teacher.

\section{Discussion}

Children's emerging understanding of science concepts requires guidance from teachers. These examples of teacher and child interactions also supported understanding of concepts of magnification and use of magnifying glasses and microscopes. Abstract thinking enables being able to generalise different experiences across different contexts. Imagination can also be seen as another feature in the development of abstract thinking (Vygotsky 2016). With the teacher's participation, the children gained knowledge of scientific words to label and define their observations. These educational experiments provided experiences to enable these children to enrich their understanding of the concept of 'small' to also include 'atoms' as very small, three-dimensional entities within everyday things.

\section{The Need for Visual Experiences}

Breaking objects down to the fundamental elements was provided by activities, focused on 'small'. Nonetheless, the deconstructions in themselves did not enable the children to extend their imagination to a non-visual level. These children could not go beyond their direct experiences, as previously described by Pramling (2015). Fortunately, we now have the means to provide more visual aids/experiences of a non-visual level with various forms of equipment and technology. The video animation experiences provided children with opportunities to recognise that smaller things of different kinds exist within everyday items.

The fact that it was the visual experience of the transitions between different levels of size strengthens the argument made by Vygotsky (2016) that imagination is, in fact, enabled by providing relevant experiences. Animations provided the opportunities to visualise the transfer between the macro-level and the abstract sub-microscopic level of chemistry, in order to accept that water is made of small things that are not directly visual. Visualisations are becoming increasingly accessible through 
computer simulations of the sub-microscopic level. This may be a solution to a longstanding problem for chemistry, namely being able to change worldviews to recognise the particulate nature of matter (Novick and Nussbaum 1978).

\section{Practical Chemical Methods}

Across the series of activities included in this study, the children became very capable of using the mortar, magnifying glasses, and microscopes. This process initially required help from the teacher, but over time, the children became very skilled in using these tools. Magnification and the use of the magnifying glass were the most challenging of the chemical methods used. One example of the difficulties that this presented to the children was that the magnifying glass, at first, was intuitively seen by the children as something that made their eyes bigger, a conclusion that was easily confirmed when they moved their magnifying glass towards the child sitting nearby and looked at that child's eyes, which immediately became quite large. This is one example of the importance of the role of the teacher to guide goal-oriented activities.

In this research, examples of activities designed to help children extend their thinking beyond direct sensory experiences illustrate how theoretical concepts can be enacted in practice by early childhood teachers. While one of the limitations of this study was the number of children included in the activities, an environment with children of this age is highly dynamic and the everyday words that the children include in their discussion are many and discussion changes swiftly. In these teacher-guided activities, it was important to expand children's own ideas expressed in their own everyday words and this does necessitate small groups of children to maximise interactional opportunities.

\section{Conclusions}

In this research, a series of play-based learning activities was designed to develop children's thinking and understanding of the scientific concept of 'small', in order to move from the visually experienced level towards more imaginative understandings of how all matter is composed of smaller elements.

In early childhood education, the transfer of knowledge and experience occurs in the interactions between children and teachers. It is an important part of the teachers' role to engage children in conversations that build knowledge through sustained shared thinking. 'Sustained shared thinking' emerges from topics of conversation between children and teachers that originate from the child's everyday experiences.

The educational experiences reported in this research provide promising ways to enrich children's learning as well as to analyse teaching strategies. There is not a lot of research on young children's specific understandings of scientific content. This research can further teachers' understanding about how to engage young children in subject-specific content about chemistry and in other various scientific fields. 
Acknowledgements Open access funding provided by Linnaeus University. The authors are grateful to the participating children, their parents, and pedagogues from the preschool involved in the project. We also acknowledge the financial support of Linnaeus University, the Crafoord Foundation, and the Längmanska Kultur Foundation (Grant No. BA19-0648).

Open Access This article is licensed under a Creative Commons Attribution 4.0 International License, which permits use, sharing, adaptation, distribution and reproduction in any medium or format, as long as you give appropriate credit to the original author(s) and the source, provide a link to the Creative Commons licence, and indicate if changes were made. The images or other third party material in this article are included in the article's Creative Commons licence, unless indicated otherwise in a credit line to the material. If material is not included in the article's Creative Commons licence and your intended use is not permitted by statutory regulation or exceeds the permitted use, you will need to obtain permission directly from the copyright holder. To view a copy of this licence, visit http://creativecommons.org/licen ses/by/4.0/.

\section{Appendix}

Transcription conventions used in the analyses and adapted from Melander Bowden (2019)

\begin{tabular}{ll}
\hline, & Punctuation mark indicates rising or continuing intonation. \\
$::$ & Punctuation mark indicates rising intonation. \\
$\mathfrak{f}$ & Colons are used to indicate prolongation or stretching of the immediately prior sound. \\
& Pound signs indicate that speech between them is produced with a happy, playful voice. \\
$* *$ & Underlining indicates some form of stress or emphasis. \\
& Very loud speech is indicated by upper case. \\
& Descriptions of gestures and actions are delimited between two identical symbols. \\
& Name in lower case indicates a child. \\
& Breaks within the transcription indicated by repeated full stops \\
\hline
\end{tabular}

\section{References}

Adbo, K., \& Vidal Carulla, C. (2019). Designing play-based learning activities in the preschool environment. Chemistry Education Research \& Practice, 20(3), 542-553.

Allen, M. (2015). Preschool children's taxonomic knowledge of animal species. Journal of Research in Science Teaching, 52(1), 107-134.

Eshach, H. (2006). Science literacy in primary schools and pre-schools. New York, NY: Springer.

EU Regulation. (2016). Regulation 2016/679 of the European Parliament and of the Council of 27 April 2016 on the protection of natural persons with regard to the processing of personal data and on the free movement of such data, and repealing Directive 95/46/EC (General Data Protection Regulation). Retrieved from https://eur-lex.europa.eu/legal-content/EN/TXT/PDF/?uri=OJ:L:2016:119:F ULL.

Fleer, M. (2011). "Conceptual play": Foregrounding imagination and cognition during concept formation in early years education. Contemporary Issues in Early Childhood, 12(3), 224-240.

Fleer, M. (2015). A cultural-historical model of early childhood science education. In M. Fleer \& N. Pramling (Eds.), A cultural-historical study of children learning science: Foregrounding affective imagination in play-based settings (pp. 199-211). Dordrecht: Springer. 
Fragkiadaki, G., \& Ravanis, K. (2015). Preschool children's mental representations of clouds. Journal of Baltic Science Education, 14(2), 267-274.

Goodwin, C. (2000). Action and embodiment within situated human interactions. Journal of Pragmatics, 32(10), 1489-1522.

Goodwin, M. H., Cekaite, A., \& Goodwin, C. (2012). Emotion as stance. In A. Peräkylä \& M. L. Sorjonen (Eds.), Emotion in interaction (pp. 16-41). Oxford: Oxford University Press.

Hedegaard, M. (2008). The educational experiment. In M. Hedegaard \& M. Fleer (Eds.), Studying children: a cultural-historical perspective (pp. 181-201). New York, NY: Open University Press.

Hedegaard, M. (2016). Imagination and emotion in children's play: a cultural-historical approach. International Research in Early Childhood Education, 7(2), 59-74.

Hedegaard, M., \& Chaiklin, S. (2005). Radical-local teaching and learning: a cultural-historical approach. Aarhus: Aarhus University Press.

Hedegaard, M., \& Fleer, M. (2013). Play, learning and children's development. Everyday life in families and transition to school. New York, NY: Cambridge University Press.

Heritage, J. (1984). A change-of-state token and aspects of its sequential placement. In J. Maxwell Atkinson \& J. Heritage (Eds.), Structures of social action: studies in conversation analysis (pp. 299-345). Cambridge: Cambridge University Press.

Johnston, J. (2014). Emergent science: Teaching science from birth to 8. New York, NY: Pearson.

Larsson, J. (2013). Contextual and conceptual intersubjectivity and opportunities for emergent science knowledge about sound. International Journal of Early Childhood, 45(1), 101-122.

Melander Bowden, H. (2019). Problem-solving in collaborative game design practices: Epistemic stance, affect and engagement. Learning, Media and Technology, 44(2), 124-133. https://doi. org/10.1080/17439884.2018.1563106.

Mondada, L. (2018). Multiple temporalities of language body in interaction: Challenges for transcribing multimodality. Research on Language and Social Interaction, 51(1), 85-106.

National Agency for Education. (2018). Curriculum for the preschool Lpfö 18. Stockholm, Sweden. Retrieved from https://www.skolverket.se/publikationer?id=2704.

Novick, S., \& Nussbaum, J. (1978). Junior high school pupils' understanding of the particulate nature of matter: an interview study. Science Education, 62(3), 273-281.

Pink, S. (2014). Doing visual ethnography (3rd ed.). Thousand Oaks, CA: Sage.

Pramling, N. (2015). Theoretical and conceptual insights-representations in science. In M. Fleer \& N. Pramling (Eds.), A cultural-historical study of children learning science: Foregrounding affective imagination in play-based settings (pp. 193-195). Dordrecht: Springer.

Russo, M. (2008). For the birds!: Seeing, being and creating the bird world. Young Children, 63(1), 26-30.

Sackes, M. (2015). Kindergartners' mental models of the day and night cycle: Implications for instructional practices in early childhood classrooms. Educational Sciences-Theory \& Practice, 15(4), 997-1006.

Siraj-Blatchford, J. (2001). Emergent science and technology in the early years. Scientific and Technological Education for Small Children. Santiago: XXIII World Congress of OMEP.

Siraj-Blatchford, I. (2009). Conceptualising progression in the pedagogy of play and sustained shared thinking in early childhood education: a Vygotskian perspective. Education and Child Psychology, 26(2), 77-89.

Siraj-Blatchford, I. (2010). An ethnographic approach to researching young children's learning. In G. Mac Naughton, S. Rolfe, \& I. Siraj-Blatchford (Eds.), Doing early childhood research. International perspectives on theory \& practice (pp. 271-290). London: Open University Press.

Siry, C., Ziegler, G., \& Max, C. (2012). "Doing science" through discourse-in-interaction: Young children's science investigations at the early childhood level. Science Education, 96(2), 311-326.

Sveriges Kommuner och Landsting. (2017). Fakta förskola. Stockholm Sweden: Retrieved from https ://skl.se/skolakulturfritid/forskolagrundochgymnasieskola/forskolafritidshem/forskola/faktaforsk ola.3292.html.

Veresov, N. (2010). Introducing cultural-historical theory: Main concepts and principles of genetic research methodology. Cultural-Historical Psychology, 4, 83-90.

Vygotsky, L. S. (1987). The development of scientific concepts in childhood. In R. W. Rieber \& A. S. Carton (Eds.), The collected works of L. S. Vygotsky (Vol. 1, pp. 167-241). Dordrecht: Springer.

Vygotsky, L. S. (2016). Play and its role in the mental development of the child. Translated by Veresov, N. \& Barrs, M. International Research in Early Childhood Education, 7(2), 3-25. 
Publisher's Note Springer Nature remains neutral with regard to jurisdictional claims in published maps and institutional affiliations. 